УДК 636.71.8.087.7

(C) 2015

Маслак Ю. В., кандидат ветеринарних наук,

Собакар А. В., асистент

Харківська державна зооветеринарна академія

\title{
ЗАСТОСУВАННЯ БІЛКОВО-ВІТАМІННИХ КОРМОВИХ ДОБАВОК ДРІБНИМ ТВАРИНАМ
}

\section{Рецензент - кандидат ветеринарних наук О. В. Маценко}

У статті наведений огляд даних літератури по застосуванню у тваринництві білково-вітамінних добавок. Розглянуто склад препарату «Біостим-40» для собак, який за рахунок вмісту лише натуральних складових (протеїну, незамінної кислоти метіоніну та аскорбінової кислоти) має позитивний вплив на організм собак. «Біостим-40»- ие оригінальна розробка технологічного інституту молока і м'яса Украӥнської академї аграрних наук. Констатовано, щуо в літературних джерелах обмаль інформаџії про застосування та вплив на організм собак білкововітамінних добавок для дрібних тварин, зокрема преnapamy «Біостим-40».

Ключові слова: білково-вітамінні добавки, протеїн, метіонін, аскорбінова кислота.

Постановка проблеми. За останні роки в годівлі тварин застосовується велика кількість харчових добавок та препаратів, які містять у своєму складі білки, амінокислоти, вітаміни, макрота мікроелементи. Вони використовуються для балансування раціонів з невистачаючих елементів живлення, підвищення перетравності та застосування поживних речовин раціонів, корегування процесів обміну речовин та профілактики стресових станів тварин. Всі добавки мають специфічні властивості та, в залежності від дози, порізному впливають на організм тварин. У випадку ïх згодовування в оптимальній кількості добавки мають стимулюючу дію, а в підвищеній призводять до небажаних наслідків і навіть до отруєння тварин. Отже, їх застосування має базуватися на знаннях їх впливу на організм та технології застосування в годівлі тварин $[1,2]$.

Аналіз останніх досліджень i публікацій, у яких започатковано розв'язання проблеми. Білково-вітамінні добавки можна застосовувати як джерело енергії тваринам за різних хвороб, у разі яких розвивається кахексія, гіпоальбумінемія, блювота та діарея. У собак забезпечення 25$45 \%$ енергії за рахунок білків (30-50\% у котів) попереджує зниження м'язової ваги. В разі тяжкого перебігу хвороб виникає дисбаланс між інтенсивністю утворення вільних радикалів та рівнем антиоксидантного захисту, тому доцільно збагачувати раціон хворих тварин антиоксидантами [9-11].

До 50 \% госпіталізованих дрібних тварин мають дефіцит поживних речовин, що призводить до критичного стану тварин, у тому числі до зниження імунітету, підвищення чутливості до інфекцій, навіть до летального наслідку. Тому важливо забезпечити хворим тваринам нормовану годівлю [11].

Р. В. Мальчиков досліджував вплив біологічно активної добавки «Трансферол» на організм службових собак [5]. О. Г. Сейн встановив зміни гематологічних показників собак під час застосування комплексної біологічно активної добавки [6]. Науково обгрунтованих даних по застосуванню білково-вітамінного препарату «Біостим40» у літературних джерелах ми не знайшли.

Мета досліджень - огляд даних літератури по застосуванню білково-вітамінних добавок дрібним тваринам.

Завдання дослідження - проаналізувати джерела вітчизняної та зарубіжної літератури щодо застосування собакам білково-вітамінного препарату «Біостим-40».

Матеріали і методи досліджень: джерела інформації про застосування білково-вітамінних препаратів тваринам, зокрема собакам; теоретичний аналіз інформаційних джерел із застосування білково-вітамінних препаратів собакам.

Результати досліджень. Білково-вітамінні добавки мають комплексну дію на організм тварин. Біохімічний склад білково-вітамінних добавок забезпечує позитивний вплив на організм тварин і має лікувальну та профілактичну дію за рахунок вмісту високоякісного протеїну, незамінних амінокислот та комплексу вітамінів.

Білково-вітамінні добавки в разі регулярного застосування можна використовувати 3 лікувальною та профілактичною метою в наступних випадках: у випадку захворювання серця і судин (виникає підвищення еластичності і міцності судин, спостерігається антикоагуляційний ефект); у випадку захворювань нервової системи (компоненти добавок мають седативну дію); в разі 


\section{ВЕТЕРИНАРНА МЕДИЦИНА}

захворювань шкіри (добавки є джерелом речовин, що мають протизапальну дію і сприяють процесам епітелізації та загоєння у випадку уражень шкірних покривів); у разі захворювань травної системи (нормалізується моторна функція кишківника, дезінтоксикаційна функція печінки); за метаболічних порушень.

Останнім часом набула популярності білкововітамінна добавка «Біостим-40» серед власників собак. Препарат добре поїдається тваринами i сприяє нормалізації роботи шлунково-кишкового тракту, формуванню кістяка, зміцненню та покращенню структури шкірного покриву, підвищенню резистентності. Також таблетовану форму препарату можна застосовувати собакам у разі втрати апетиту.

Оцінка забезпеченості тварин поживними речовинами має грунтуватись на інформації про те, як харчувалась тварина, результатах іiі клінічного дослідження, визначення маси тіла, вгодованості i також показниках лабораторних тестів. Проте зміни основних лабораторних індикаторів недоотримання тваринами поживних речовин (концентрації альбумінів, сечовини та холестеролу в сироватці крові, кількості еритроцитів і лейкоцитів у крові) звичайно неможливо відрізнити від аналогічних параметрів за супутніх хвороб. Інші маркери забезпеченості тварин поживними речовинами (концентрація преальбуміна, трансферина, фібронектина, ретинолзв'язуючого протеїна, церулоплазміна, антитрипсина, кислого глікопротеїна та C-реактивного білка) у собак i котів остаточно не з'ясовані.

У хворих тварин збільшується вивільнення цитокінів, запальних медіаторів і активізується нейрогормональна відповідь. Ці медіатори індикують стан підвищеного обміну речовин, за якого збільшується витрата енергії та споживання кисню. Амінокислоти мобілізуються 3 депонованого в організмі азоту, особливо скелетних м'язів, і використовуються для глюконеогенезу. В такій ситуації організм не в змозі знизити катаболізм протеїну, що призводить до витрачення структурних білків. Катаболічна стадія триває доти, доки не будуть видалені цитокіни й нейроендокринні медіатори. Мобілізація запасів білка в організмі знижує м'язову силу і масу, і це при-

\section{БІБЛІОГРАФІЯ}

1. Алексеев B. A. Повышение полноценности кормления молодняка свиней при использовании в рационах витаминных добавок : автореф. дисс. на соиск. уч. степени д.с.-х.н. : спец. 06.02.02 «Кормление сельскохозяйственных животных и технология кормов» / В. А. Алексеев. - Дубро- зводить не лише до зниження маси тіла і слабкості скелетних м' язів, але й до виснаження гладенької мускулатури і серцевого м'яза. Для усунення негативного азотного обміну у тварин з тяжкими метаболічними процесами може знадобитись забезпечення протеїном у кількості, що значно перевищує нормальні мінімальні потреби. Проте слід пам'ятати, що тваринам із синдромом печінкової енцефалопатії та уремією, виникає необхідність зниження споживання білка 3 кормом. I навпаки, тваринам $з$ обширними опіками та довготривалим інтраперитонеальним дренуванням може знадобитись більш високий рівень споживання білка. Протеїн, який отримують тварини, повинен бути високо перетравним і містити всі незамінні амінокислоти.

Доцільно збагачувати раціон тварин антиоксидантами, бо в разі захворювань в організмі тварин утворюються вільні радикали. Вільні радикали - це нестабільні молекули, які утворюються внаслідок екзогенних та ендогенних механізмів і викликають оксидативне ураження компонентів клітин, що в свою чергу може призвести до дисфункції органів. Організм хворої тварини протидіє оксидативному ураженню вільними радикалами своєю антиоксидантною системою, яка утворюється супероксиддисмутазою, глутатіонпероксидазою, каталазою, вітаміном Е, аскорбіновою кислотою [3].

Метионін - це незамінна амінокислота, необхідна для синтезу холіну, фосфоліпідів та ліпотропного ефекту, має дезінтоксикаційну дію [4].

У хворих тварин часто розвивається дефіцит поживних речовин, тому застосування білкововітамінних добавок, зокрема препарату «Біостим-40», знижує тяжкість захворювань та попереджує летальність.

Висновок. У літературі висвітлено багато наукових досліджень, присвячених вивченню впливу білково-вітамінних добавок на організм сільськогосподарських тварин та збільшення їх продуктивності $[4,7,8]$. В літературних джерелах обмаль інформації про застосування білкововітамінних добавок дрібним тваринам. Тому дослідження впливу препарату «Біостим-40» на організм собак є актуальним.

вицы, 1994. - 40 с.

2. Борин A. B. Оптимизация уровня белкововитаминно-минеральных добавок в рационах молодняка свиней : автореф. дисс. на соиск. уч. степени к.с.-х.н. : спец. 06.02.02 «Кормление сельскохозяйственных животных и технология 


\section{ВЕТЕРИНАРНА МЕДИЦИНА}

кормов» / А. В. Борин. - Саранск, 2003. - 20 с.

3. Жукова I. O. Патогенез ушкодження клітинних структур організму активними формами кисню та корекція цих процесів антиоксидантами / І. О. Жукова, Ю. С. Світлична-Кулак // Проблеми зооінженерії та ветеринарної медицини : зб. наук. праць. - 2013. - Вип. 26, Ч. 2. - С. 15-19.

4. Камбур М. Д. Вплив метіоніну та лізину на обмінні процеси в організмі телят / М. Д. Камбур, Н. М. Сорока, А. А. Замазій // Вісник Полтавської державної аграрної академії. - 2007. №3. - C. 42-44.

5. Мальчиков Р. В. Использование биологически активной добавки «Трансверол» в кормлении служебных собак / Р.В.Мальчиков // Ученые записки Казанской государственной академии ветеринарной медицины им. Н. Э. Баумана. 2013. - T. 214. - C. 25-27.

6. Сейн О.Б. Гематологические показатели при использовании комплексной биологически активной добавки / О.Б. Сейн, В. А. Стариков // Вестник Курской государственной сельскохозяйственной академии. - 2014. - №1. - С. 65-67.

7. Тарасенко Л. О. Ефективність застосування кормової добавки пектиновмісної поросятам на дорощуванні / Л. О. Тарасенко // Вісник Полтавської державної аграрної академії. - 2014. - №2. C. $112-115$.

8. Улитько В.E. Биологическое воздействие новых биогенных добавок на микробиоциноз пищеварительного тракта и переваримость питательных веществ бройлерами / В.Е. Улитько, О. Е. Ерисанова // Тезисы докладов международной научно-практической конференции посвященной 60-летию зоотехнической науки Белоруссии. - Жодино. - 2009. - С. 290-292.

9. Хохрин С.Н. Кормление собак и кошек : справочник / С. Н. Хохрин. - М. : Колос, 2006. $248 \mathrm{c}$.

10. Nery $J$. Influence of dietary protein content and source on fecal quality, electrolyte concentration and digestibility in dogs differing in body size / J. Nery, V. Biourge, C. Tournier // Journal of Animal Science. - 2008. - Vol. 88. - P. 159-169.

11. Swansoi K. S. Diet affects nutrient digestibility, hematology and serum hemistry of senior and weanling dogs / K. S. Swansoi, K. N. Kuzmuk, L. B. Schook // Journal of Animal Science. - 2004. Vol. 82. - P. 1713-1724. 